\title{
Luigi Derla, Il diritto e il rovescio del «Curé de village» di Balzac
}

\section{Marco Stupazzoni}

\section{Q OpenEdition}

1 Journals

\section{Edizione digitale}

URL: https://journals.openedition.org/studifrancesi/40922

DOI: $10.4000 /$ studifrancesi.40922

ISSN: 2421-5856

\section{Editore}

Rosenberg \& Sellier

\section{Edizione cartacea}

Data di pubblicazione: 1 juillet 2004

Paginazione: 209

ISSN: 0039-2944

\section{Notizia bibliografica digitale}

Marco Stupazzoni, «Luigi Derla, I/ diritto e il rovescio del «Curé de village» di Balzac», Studi Francesi [Online], 142 (XLVIII | I) | 2004, online dal 30 novembre 2015, consultato il 09 septembre 2021. URL: http://journals.openedition.org/studifrancesi/40922 ; DOI: https://doi.org/10.4000/studifrancesi. 40922

Questo documento è stato generato automaticamente il 9 septembre 2021.

\section{(c)}

Studi Francesi è distribuita con Licenza Creative Commons Attribuzione - Non commerciale - Non opere derivate 4.0 Internazionale. 


\section{Luigi Derla, Il diritto e il rovescio del "Curé de village» di Balzac}

Marco Stupazzoni 


\section{NOTIZIA}

LUIGI DERLA, Il diritto e il rovescio del «Curé de village» di Balzac, «Testo. Studi di teoria e storia della letteratura e della critica», 43, nuova serie, Anno XXIII, gennaio-giugno 2002, pp. 127-136.

1 Nelle intenzioni programmatiche di Balzac, Le Curé de village è concepito come un'opera dai toni dichiaratamente apologetici e tesa, in particolare, a celebrare la sublime potenza del pentimento cattolico: «loin d'offrir l'intérêt romanesque, assez avidement recherché par les lecteurs» - leggiamo nella prefazione del 1841 -, il romanzo avrebbe dovuto costituire, secondo lo scrittore, solo «l'antefatto del «vero libro»» ponendosi in tal senso, agli occhi dei lettori, più come un romanzo a tesi che come un testo meramente letterario.

2 In realtà, osserva Derla, Le curé occupa un posto a sé nell'architettura della Comédie humaine soprattutto per «l'originalità della tecnica e della struttura narrative» (p. 127): il romanzo di Véronique, di Tascheron e, di riflesso, dell'abbé Bonnet riflette anzitutto una storia di passioni, di delitti, di espiazioni che si ritaglia e si riconquista una propria autonomia romanzesca a discapito del marchio indelebile di 'romanzo cattolico' che Balzac avrebbe voluto imprimere alla sua opera.

Il «carattere intimamente contraddittorio» del Curé, puntualizza bene l'A. nella parte conclusiva del suo intervento, deriva dall'«effetto contrario a quello che Balzac si proponeva: /.../ non la condanna ma l'apoteosi della passione; non la sublimazione della santità cattolica, ma di una santità, quella di Véronique, romanzesca, frutto del suo cordoglio per l'amante che la giustizia umana le ha ucciso, e che il prete le imponeva di rinnegare» (p. 137). 